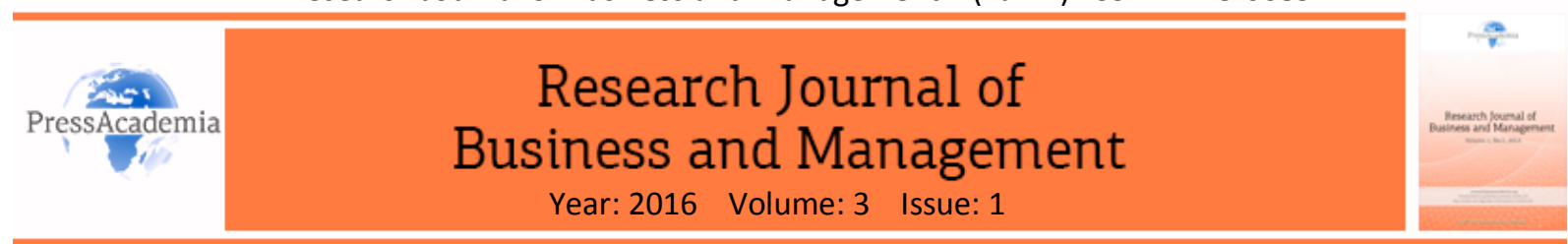

\title{
THE DYNAMICS AND DECISION MAKING PROCESS OF CONDUCTING POST-GRADUATE STUDY IN SCHOOL OF MANAGEMENT
}

\author{
DOI: 10.17261/Pressacademia.2016116567 \\ Kamaludin', Berto Usman² \\ 1 University of Bengkulu. kamaludin@unib.ac.id \\ ${ }^{2}$ University of Bengkulu. berto usman@unib.ac.id
}

\begin{abstract}
This research is officially intended to investigate the dynamic alteration relating to the knowledge of management fields, particularly in responding the unpredictable changes of either internal or external environments. Besides, we employ the quantitative and qualitative approaches in discovering the triggering factors cause the non-management students conducting their study in the graduate, and post graduate school of management. We use 80 respondents comprise of 30 students who study in Doctoral program and 50 students from Master program. This sample is meticulously selected by implementing judgement sampling method and involving students who have nonlinear background referring to management studies. Hereby, we note that there are various types of reasons from the respondents to commence their study in management program (Master and Doctoral). These all factors are regarding to students' decisions, process, tuition fee, social economics background, motivation, facilities, references, reputations, and the products offered by the service provider. We inferred that the main factor which makes the management program become more interesting and remarkably growth than the other fields of study, is relating to its ability in responding the significant changes of internal or external needs of users. Also, the social science knowledge obviously performs the dynamics alteration in various perspectives, especially in terms of human resource management, operational and production, marketing, finance, information system, and service sector. Therefore, management program seems to be more interesting and shows promising progress with respect to the origin of social science.
\end{abstract}

Keywords: Management, decisions, quality, process, motivation, reputation.

JEL Classification: M10

\section{INTRODUCTION}

In the recent days, the number of people who wants to conduct their study in school of management is increasing significantly. It can be seen from the high interest of students who take master and doctorate in management program as their choice. This phenomenon is also followed by the dynamic alteration of business, relating to globalization which has offered a wide opportunity for job applicants to work as professionals (Bruce et al., 2010). Besides, self empowerment by participating in educational process can be directed toward entrepreneurships activity, in which the potential and managerial skill of every individual is optimally explored to conduct business activity (Fisher et al., 2007).

The development of business widely opens an opportunity in terms of job availability. Hereby the process of self improvement conducted by job applicants is not limited on the undergraduate level only, but also has moved to graduate or even postgraduate level. It denotes that people who have good education incline to have better life future and bigger opportunity of getting the appropriate job. DIKTI (Directorate of higher education Republic of Indonesia) has revealed that there are more than 1.005 higher education (state and private) providers which have been focusing their concerns in school of management. DIKTI shows that the increasing number of department of management is obviously in line with the growing number of master and doctorate program. In 2014, it is cited that there were 310 graduate programs for master of management and 32 
doctorate programs in management. These programs are separated in two form, namely applied and science program.

Specifically, DIKTI ${ }^{1}$, Okezone ${ }^{2}$, and Detik.com ${ }^{3}$ had announced that in May 2014, department of management had been chosen as the most favorite program in Indonesia following by accouting program, Information and Technology (IT), psychology, communication, pharmacy, and medical respectively. Further, Wood \& Gordon, (2009) report that scholar who finished their undergraduate program with non management background actively participate studying about management sciences in graduate program. This phenomenon is triggered by the necessity of preparation of being a leader in future. Moreover, due to the widely open of career opportunities, the number of prospective student who has interests with management studies is increasingly higher. Yeaple, (2010); Dillon et al., (2011) also point out that this path considerably helps the potential students in determining whether they will continue their study to graduate program or not. They assume that it is essential for them to add more new insight in regard to managerial skills. The motive is particularly supported by the need of managerial skills about how to manage people in order to achieve organizational goals (Cornuel, 2011).

As pointed out by the previous studies, the need of managerial skills is commonly needed by the people who have strategic position in determining the optimum decision (Latham \& Brown, 2006). Management studies are conjectured to provide the students as decision makers. In particular, the available alternative options of management studies comprise of financial management, marketing management, operational and production management, human resource management, and then system information of management. Gupta et al., (2007) document that the various options of specific majors will not turn to a difficult challenge for the student in conducting their study in management studies. Conversely, the dynamic of management studies is obviously needed for providing each individual with numerous numbers either of soft skills or hard skills. Herewith, virtually all managerial skills which are commonly needed by the professional focus on the service activity in public management, and non-profit organization.

The dynamic development of management science provides a great opportunity for college to prepare prospective students as individuals who can take strategic decisions precisely (Wood \& Gordon, 2009; Yeaple, 2010; Linden et al., 2013). Universities as institutions and the providers of education are also getting new challenges stemming from the needs of stakeholders at the international level. Ritz \& Martin, (2013) mention that until now, market demand and global challenges are the top priorities for school of management in order to produce competitive outputs. Additionally, Kuipers (2011) adds that the factors such as time changes, the support of capable human resources, human aspects, the presence of industrial society, the increasing number of people who has awareness relating to information, globalization, and business competition are the challenges that must be anticipated by the graduates of school of management.

The high demand with regard to the implementation of business school has been followed by the increasing challenges faced by graduates. Schools of management are required to provide students with optimum quality and flexibility to the changing of times and global challenges (Fisher et al., (2007). This study specifically identifies the factors of what make students with non-management background are attracted to continue their studies at the graduate level, particularly on master and doctorate program with the specific area of management studies. In addition, the comparative dynamism in respect to the advance of management science will be explored, in which this research is also focused to identify and investigate the broadening development of interest and expectations from students who decide to continue their formal education in management programs. In order to gain robust result, we employ the judgement sampling technique in collecting the samples. Also, we use descriptive quantitative analysis and in-depth interview in elaborating the influencing factors attributing to students' decision for studying at school of management.

\footnotetext{
${ }^{1}$ Data can be retrieved on the official website of Directorate Higher Education on URL page: www.forlap.dikti.go.id

${ }^{2}$ News can be retrieved on the on-line media Okezone.com on page: www.kampusokezone.com/read/2014/05/26/373/990241/manajemen-prodi-terfavoritdi-snmptn-2014.

${ }^{3}$ News can be accessed on the on-line media Detik.com on page:

News.detik.com/read/2014/05/26/180450/2592871/10/manajemen-jadi-primadona-di-snmptn-ini-daftar-10-jurusan-favorit.
} 
The structure of our paper is designed as follows. Firstly, we present the theoretical background to support the content and elaboration relating to the dynamics and decision making proces to study in management studies. Secondly, we explain the sampling method, data generation, descriptive analysis about demographical profile of respondents, and the procedures of correlation analysis of inter-variables used in the study. Thirdly, we develop the results and discussion regarding to the output. Finally, we comprehensively conclude the finding of this paper along with the opportunity of developing the future research.

\section{LITERATURE SURVEY}

\subsection{Motivation and Satisfaction Theory}

Motivation can be employed as energy, lead to persistence, and enthusiasm in order to conduct a specific task assigned to someone. Studies on motivation have long earned its own focus, thus providing an appeal to be elaborated in greater depth. Lussier (1997) reveals that motivation is a hope to achieve a goal. While Robbins (2007) states that motivation is the result of the interaction between individual in a formal situation, so there is an attempt to do the same thing in achieving that goal. Procedures taken to achieve these objectives must be sustained, in which one's motivation in general is derived from organizational goals. Furthermore, Robbin (2007) also points out that the theory of motivation can be classified into satisfaction theory, and the classical theory of motivation.

Satisfaction theory or famously known as content theory, is an approach based on the factors of individual needs and satisfaction that causes someone acting and behave in a certain way. This theory focuses on the factors comprising of individual's strengthens, directing, supporting, and decision in stopping certain behavior. The motive is relating to person's motivation to meet the needs of material and non-material satisfaction obtained from the results of his work. The level of satisfaction will reflect the spirit of person. Further, Classical motivation theory as stated by FW Taylor (single needs theory) reveals that an individual is able to meet the needs and satisfaction of any biological. Herzberg's two factor theory of motivation also reveals that the ideal motivation can stimulate businesses to perform tasks that can be executed with skills and good opportunities.

\subsection{Expectancy for Studying in Graduate School of Management}

The concept implemented on the selection process and the decision to commence a program can be associated with expectancy theory. According Kreitner \& Kinicki (2000), motivation is a series of attitudes and values that can affect individuals to achieve something specific for their intended purposes. Hereby, attitudes and values are the dimension that are not visible to the human eyes, in which the attitude giving someone the power to encourage individuals in initiating and directing the behavior toward activity.

Victor Vroom's expectancy theory (1964) as quoted by Stahl \& Harrell (1981) states that individuals tend to act in a specific way, particularly with the basic expectation that such actions can be followed by results preceded from certain businesses. The results of these efforts are obviously the main attraction for another people as an example to follow. Stahl \& Harrell (1981) also point out that the expected behavior in a person's work will soon increase. This results in the positive causal relationships which is implemented and measured by specific performance.

Moreover, the theory of needs is developed by Maslow (1943). He states that human needs are divided into five categories which come out into the hierarchy of prepotency, namely (1) Basic needs, related to human physiological needs including the need for food, beverages, housing and so forth. (2) The need for a sense of security, related to security concerns of protection and stability. (3) Social needs which are triggered due to the need for a sense of friendship, kinship, and feeling to be accepted in a group. (4) The need for recognition (selfesteem), which became one form of manifestation of one's self recognition. Self recognition can be associated with status, position, confidence, reputation, achievement, appreciation, self-respect, and appreciation. (5) The need of self-actualization, the manifestation of all forms of self-expression or the potential self-development. Further, based on the a priori explanation, it is obviously known that consumers will have numerous reasons for continuing their education with respect to expectancy of studying in school of management. 


\subsection{Planned Behavior of Studying in Graduate School of Management}

Ajzen (1991) revised the theory of reasoned action (TRA) and replaced it with the theory of planned behavior (TPB). This theory fundamentally explains that the behavior of an individual is formed by certain ways. According to Ajzen and Fishbein (1985), attitude and personality of individuals contribute to a particular behavior only if it is not directly influenced by several factors associated with the behavior. In line with the concept of TRA, there are three concepts that are related as a determinant of intense as expressed by Ingram et al., (2000) as follows.

\section{Figure 1: Theory of Reasoned Action Model}

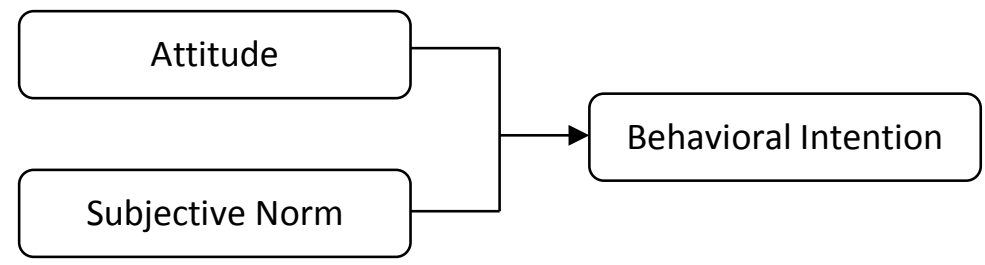

Sources: Fishbein \& Ajzen, (1985).

Ingram et al., (2000) explain that TRA model relating to student's decision to major in management is associated to several factors namely, 1) Attitude toward the behavior, which leads to the level that is owned by a person in making decision, and to make the results of the evaluation is favorable or unfavorable to a behavior, 2). Subjective Norm, is a value that refers to the social pressures faced by an individual to display certain behavior or decide not to show such behavior, 3). The degree of perceived behavioral control refers to the ease or difficulty level displaying certain behaviors as well as assumptions made by individuals, who reflect past experience as an ingredient of anticipation in facing challenge or problems. Further, the concept of TRA has been extended to TPB as can be seen in Figure 2.

Figure 2: Theory of Planned Behavior

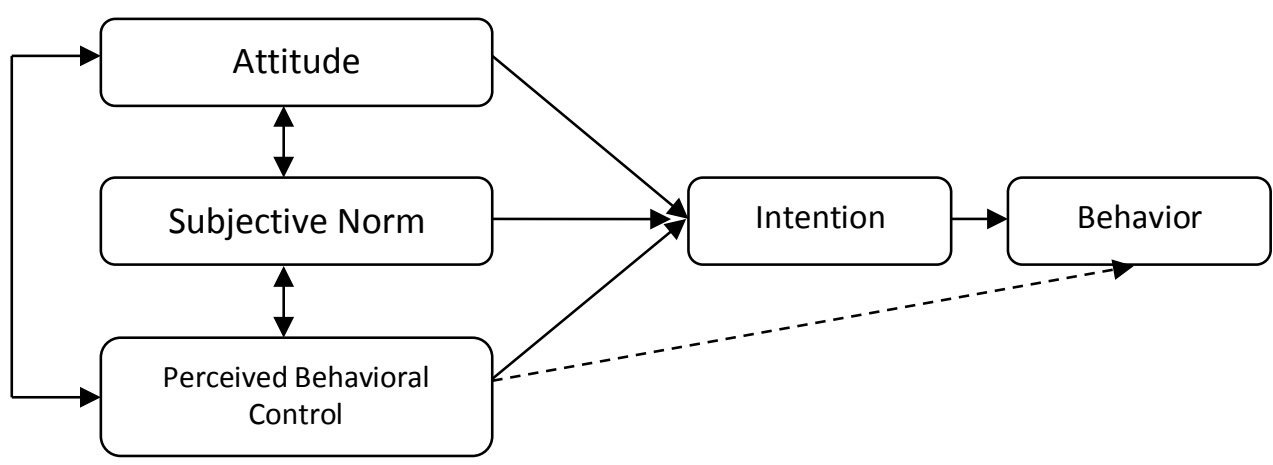

Sources: Ajzen, (1991).

Seminal studies have been conducted to identify and investigate the behavior of individual consumers, particularly in making decisions relating to the use of interest toward products or services in education. It is not a simple activity, and even quite difficult. In this case, Engel et al., (1994) define consumer behavior as activities that directly involve themselves to acquire, consume, and spent the best product, either goods or services in education itself. This procedure is including the decision process that precedes the captured activity. Thus, it can be emphasized that consumer behavior in the field of education is a chain of process.

Furthermore, Kotler (2003) mentions that the attitude tends to be described as evaluation that reflects the emotional feelings and tendencies to act favorably or unfavorably. In this context, the attitude is consistently expected to form a pattern or trend of individuals. This is in line with the research as reported by Engle et al., 
(1994) in which the attitude is defined as thorough evaluation activities that allows individuals to give feed backs, or responds in a favorable or unfavorable way.

Theoretically, TPB is built as the development of TRA. Dharmesta (2002) demonstrates that TRA implementing the concept of consumer behavior and buying behaviors which are influenced by the intention of the individual, the attitude toward behavior, and subjective norms. In particular, TRA is the fundamental concept of TPB. It explains that attitudes will influence the behavior of a person through a decision-making process which is conducted carefully and rationally. According to Sihombing (2003), this process impacts on three important areas, where 1) the behavior is not only influenced by the general attitude, but behavior can also be affected by a more specific attitude toward an object judged. 2) The behavior of a person is not only influenced by the attitude, but also influenced by subjective norms. This norm is closely related to the level of a person's beliefs about what other people want to do. 3) Attitude toward behavior along with subjective norms would include an intention to behave. According to the theories of TRA and TPB, it can be seen that the intention of acting as potential students in school of management are strongly shown by the high needs of consumers itself.

\section{DATA AND METHODOLOGY}

\subsection{Sampling and Procedure}

This study is a combination of quantitative and qualitative research, in which trying to investigate and identify the factors that make students with non management background deciding to continue their formal studies at the graduate school of management. In this regard, respondents are obtained by employing judgment sampling method, and should have meticulously following these criterion, 1) scholars who enroll their program in master of management, 2) scholars who have non-management background from their undergraduate program, 3) scholars who enroll their study in doctorate of management with non-management educational background either in undergraduate or graduate level. Hereby, we finally obtain 50 respondents from master of management program and 30 respondents from doctorate of management program who actively study in the Faculty of Economics and Business, University of Bengkulu.

\subsection{Data Generation}

The data generation performed in this study is focused by utilizing questionnaires and in-depth interview. Interview is needed in order to explore and to collect the comprehensive information relating to the factors that push students to continue their formal studies in the field of management studies. Whereas, the use of the questionnaire is intended to quantitatively identify the factors that trigger an individual to continue the formal study either in master of management of doctorate of management. In addition, the analysis is meticulously conducted by employing descriptive statistical analysis. Particularly, we measure the mean of every question in regard to respondents' perception toward the indicators of questionnaire.

In operationalizing the constructs, we adapted a subset of items from Maslow (1943), Vroom's Expectancy theories (1964) as quoted by Stahl \& Harrell (1981), Ajzen (1991), Ingram (2000), and several adjustments to Indonesian context. To ensure a high degree of reliability and result validity, the operationalization of the variables was based on several steps. First, we measure the validity and reliability of indicator by adopting the Indonesian characteristics. Second, we drop every item which shows invalid indicator in the correlation test results. Third, we employ 0.70 of Cronbach alpha as the threshold level of reliability test. Lastly, we conduct the descriptive quantitative analysis by counting the mean of every variable.

Totally, as many as 80 questionnaires were collected from master and doctorate students. The survey was grouped into two parts. The first part was intended for master students who have non management background in their undergraduate program (50 questionnaires). The second part was for those who study in doctorate program and have non management background for their undergraduate and or graduate program (30 questionnaires). As stated by Cooper \& Schindler, (2011) questionnaire is required as data collection techniques by sending a compilation of questions that needs to be filled by the respondents. Every question regarding to the employed variables in the questionnaire is equipped with alternative answers. Hereby, respondents use likert scale from 1 to 5 to indicate their answers. The specific score of each alternative answer 
consists of 1 = Strongly disagree with mean score between 1,00 and 1,80. $2=$ Disagree $(1,81-2,60), 3=$ Neither agree nor disagree $(2,61-3,40), 4=$ Agree $(3,41-4,20)$, and $5=$ Strongly agree $(4,41-5,00)$.

Moreover, we conduct the data collection by implementing in-depth interview. Interview is a form of verbal communication that is needed to obtain comprehensive information (Cooper \& Schindler, 2011). Interview method is employed to collect the data, to explore, and to gain depth information about the variables from 10 students at master of management programs, and 10 doctoral students in management program.

\subsection{Validity, Reliability Test, Correlation Inter-variables}

We acknowledge that the sample size in this study is not large, in which we have 80 respondents as consolidated samples. Nevertheless, the sample size was sufficiently large for all of the zero-order and multiple correlations to be statistically significant beyond the 0.05 level, as the reader will soon observe. Some of the smaller and insignificant partial effect may well have been significant were sample size larger, but it is always the case that probably faced by many researchers. The result of correlation test by implementing pearson correlation can be seen as follow.

Table 1: Correlation Table in Consolidated Samples $(\mathrm{N}=\mathbf{8 0})$

\begin{tabular}{|c|c|c|c|c|c|c|c|c|c|c|}
\hline \multirow{2}{*}{\multicolumn{2}{|c|}{ Variables }} & \multicolumn{9}{|c|}{ Pearson Correlation } \\
\hline & & $\overline{\mathrm{DECISION}}$ & PROCESS & TUITION & SOSEC_BACK & MOTIVATION & FACILITY & REFERENCE & REPUTATION & PRODUCT \\
\hline \multirow[t]{2}{*}{$\overline{\mathrm{DECISION}}$} & $\mathrm{R}$ & 1 & & & & & & & & \\
\hline & Prob.Sig & & & & & & & & & \\
\hline \multirow[t]{2}{*}{ PROCESS } & $\mathrm{R}$ & $0.616^{* \prime}$ & 1 & & & & & & & \\
\hline & Prob.Sig & 0.000 & & & & & & & & \\
\hline \multirow[t]{2}{*}{ TUITION } & $\mathrm{R}$ & $0.408^{* *}$ & $0.324^{* *}$ & 1 & & & & & & \\
\hline & Prob.Sig & 0.006 & 0.003 & & & & & & & \\
\hline \multirow{2}{*}{ SOSEC_BACK } & $\mathrm{R}$ & $0.349^{* *}$ & $0.240^{*}$ & $0.313^{* *}$ & 1 & & & & & \\
\hline & Prob.Sig & 0.002 & 0.032 & 0.005 & & & & & & \\
\hline \multirow{2}{*}{ MOTIVATION } & $\mathrm{R}$ & $0.630^{\circ "}$ & $0.737^{\circ "}$ & $0.257^{\circ}$ & $0.242^{\circ}$ & 1 & & & & \\
\hline & Prob.Sig & 0.000 & 0.000 & 0.021 & 0.030 & & & & & \\
\hline \multirow[t]{2}{*}{ FACILITY } & $\mathrm{R}$ & $0.371^{* \prime}$ & $0.657^{* *}$ & $0.421^{\prime \prime}$ & $0.265^{\circ}$ & $0.617^{* *}$ & 1 & & & \\
\hline & Prob.Sig & 0.001 & 0.000 & 0.000 & 0.043 & 0.000 & & & & \\
\hline \multirow[t]{2}{*}{ REFERENCE } & $\mathrm{R}$ & $0.271^{\circ}$ & $0.421 "$ & $0.405^{* \prime}$ & $0.296^{* \prime}$ & $0.360^{\circ "}$ & $0.548^{* *}$ & 1 & & \\
\hline & Prob.Sig & 0.023 & 0.000 & 0.000 & 0.008 & 0.001 & 0.000 & & & \\
\hline \multirow[t]{2}{*}{ REPUTATION } & $\mathrm{R}$ & $0.272^{*}$ & $0.228^{*}$ & $0.398^{*}$ & $0.351^{* *}$ & $0.375^{* *}$ & $0.278^{*}$ & $0.288^{*}$ & 1 & \\
\hline & Prob.Sig & 0.025 & 0.042 & 0.048 & 0.001 & 0.001 & 0.024 & 0.044 & & \\
\hline \multirow[t]{2}{*}{ PRODUCT } & $\mathrm{R}$ & $0.460^{* *}$ & $0.557^{* *}$ & $0.297^{*}$ & $0.482^{* *}$ & $0.416^{* *}$ & $0.445^{* *}$ & $0.384^{* *}$ & $0.403^{* *}$ & 1 \\
\hline & Prob.Sig & 0.000 & 0.000 & 0.030 & 0.000 & 0.000 & 0.000 & 0.000 & 0.000 & \\
\hline
\end{tabular}

*. Correlation is significant at the 0.05 level (2-tailed).

Source: The data was processed, 2014

We have been conducting the validity and reliability test regarding to the indicators that are used to measure the specific variables comprise of decision, process, tuition, social economy background, motivation, facility, reference, reputation, ad product. Our output have passed the validity test and performed the high reliability with the threshold level in 0.70 Cronbach alpha scores for each variable. Therefore, in order to make sure that the factors used are relating to the dynamics reasons of prospective students to continue their study in school of management, we provide the correlation Table for each variable as can be observed on Table 1.

\subsection{Demographic Profiles of Respondents}

Elaboration relating to the demographic profile of respondents is the basic information about the characteristics of respondents. Based on the results obtained by performing statistical descriptive analysis, it is known that all respondents were drawn from master of management and doctorate of management provide basic information such as the demographical characteristics. The number of respondents who has nonmanagement educational backgrounds that enrolling master and doctorate program is 80 respondents. The demographic information processed by employing descriptive analysis can be observed in Table 2 as follow. 
Table 2: Summary Statistic of Respondents' Demography

\begin{tabular}{|c|c|c|c|}
\hline \multirow{2}{*}{ Demography } & \multirow{2}{*}{ Characteristics } & \multirow{2}{*}{$\begin{array}{c}\text { Doctorate in Management } \\
\text { Total }\end{array}$} & \multirow{2}{*}{$\frac{\text { Master of Management }}{\text { Total }}$} \\
\hline & & & \\
\hline \multirow[t]{2}{*}{ GENDER } & Male & 14 & 22 \\
\hline & Female & 16 & 28 \\
\hline \multirow[t]{6}{*}{ AGE } & $20-25$ years old & 5 & 11 \\
\hline & $26-30$ years old & 11 & 12 \\
\hline & $31-35$ years old & 6 & 17 \\
\hline & $36-40$ years old & 5 & 5 \\
\hline & $>40$ years old & 3 & 5 \\
\hline & & - & \\
\hline \multirow[t]{4}{*}{ JOB } & Civil Servant & 22 & 28 \\
\hline & Lecturer & 8 & 0 \\
\hline & Entrepreneur & & 13 \\
\hline & Professional & & 9 \\
\hline \multirow[t]{5}{*}{ TENURE } & $1-5$ years old & 5 & 14 \\
\hline & $6-10$ years old & 6 & 13 \\
\hline & $11-15$ years old & 8 & 9 \\
\hline & $16-20$ years old & 9 & 8 \\
\hline & $>20$ years old & 2 & 6 \\
\hline \multirow[t]{4}{*}{ INCOME (IDR) } & 1-5 Million & 11 & 42 \\
\hline & 6-10 Million & 16 & 8 \\
\hline & 11-15 Million & 3 & 0 \\
\hline & 16-20 Million & & 0 \\
\hline \multirow[t]{7}{*}{ CITY } & Bandung & 19 & 4 \\
\hline & Bengkulu & 5 & 30 \\
\hline & Bengkulu selatan & 4 & 5 \\
\hline & Bengkulu utara & 2 & 3 \\
\hline & Kepahiang & & 3 \\
\hline & Kaur & & 3 \\
\hline & Lubuk Linggau & & 2 \\
\hline
\end{tabular}

Source: The data was processed, 2014

\section{EMPIRICAL FINDINGS}

This study uses nine indicators which reflect the preferences of each respondent in deciding to pursue graduate program in master and doctorate programs in management. The motive of using nine variables is expected to be parsimony measuring tool. Therefore, the main objective and focus of consumers can be identified comprehensively. The nine variables consist of the student's decision in education, the implementation of educational process, cost of education, socio-economic background, motivation, facilities, references, reputation, and products.

The most recent phenomenon happening today shows that there is a significant needs about skill improvement and competences, either in form of hard skills or soft skills. Besides, the needs of industry relating to the competence of human resources are driven to the rapid economic growth, so that human resources that is fully loaded with managerial and technical skills is clearly required by the market. Management program in undergraduate, graduate, and post graduate provide a specific competencies, and a core product that can lead students to meet the criteria as desired by professional market. Recently, many state and private universities widely spread throughout Indonesia area and establishing management courses in their institution. In addition, 
the recapitulation of SBNMPN 2014 as reported by okezone.com and detik.com also note management as the desirable course in Indonesia.

High interest of studying in management program is not only just a phenomenon in undergraduate level, but many business schools also accept students who pursuing graduate program in management. In fact, their educational backgrounds are totally different from management studies. For instance, in Master of Management (MM), Faculty of Economics and Business, University of Bengkulu, many graduate students who have non-management background are conducting their study in management program. They are obviously have various backgrounds such as medical, law, social and political science, police academy, institute of domestic governance, and so forth. Furthermore, there is also a graduate student at the Doctorate program in management (DIM) who previously studied in medical school, continued to graduate school of public administration program, and finally decided to study in doctorate program in management. When it is viewed from the relevance of her field, the student cannot be said having a clear linearity. However, the job condition demands the student to have managerial and conceptual competence as supporting factors in making strategic decisions. The compilation of respondents' perception obtained from the questionnaire can be summarized in Figure 3 as follow.

Figure 3: Consolidated Output of Respondents Identified from Nine Influencing Factor for Continuing study in Graduate School of Management

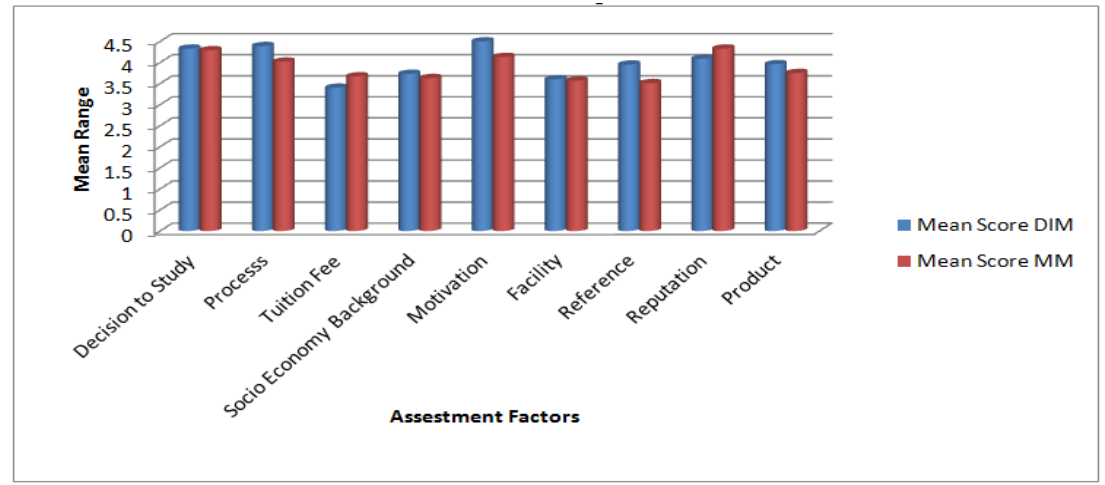

Source: The data set was processed, 2015.

"Strongly disagree" with mean score between 1,00 and 1,80, "Disagree" (1,81-2,60), "Neither agree nor disagree" (2,61-3,40), "Agree" (3,41-4,20), and "Strongly agree" (4,41-5,00).

The information provided in Figure 3 reflects that, generally respondents provide high valuation on the decision (mean score: 4.33) and motivation (mean score: 4.50) to continue their studies at the level of master or doctoral degree. The Figure is processed by employing consolidated data as the supporting information in identifying the phenomenon of students who continue their studies with non-management educational background. Moreover, the phenomenon of fresh graduate students who decide to continue their study in master program also becomes a new trend. It can be seen from the high interest of students who follow the selection into master program (see Figure 4).

In line with the research conducted by Thurau et al., (2001) students tend to have a high degree of loyalty to the institution where they had studied. Also, there is a concern that the high number of scholars who passed the undergraduate program difficult to find a job. So that, most students decide to continue their studies in hope of increasing value added and competences. Further, the rapid growth of higher education institutions tries to attract many students. The segment market of graduate students either in master or doctoral degree is widely open (Urchick, 2004; Sharabi, 2013). This is in line with the wishes of prospective students who eager to have competence in accordance with their needs and market conditions. No wonder, even though public universities are not heavily promoting, but still many students chose to continue their studies in state universities which have been recognized and have offered resources that can provide good quality services. This condition is slightly different from the conditions experienced by the private universities. Private colleges will conduct a vigorous campaign with the hope of meeting target in achieving the desired number of students. 
Information relating to the trend of students who apply and be accepted in the graduate school of management program from 2008 to 2012 can be observed in Figure 4.

Figure 4: Trend of Magister Management Students Who Followed Selection Procedure and Passed the Entry Test from 2008 to 2012

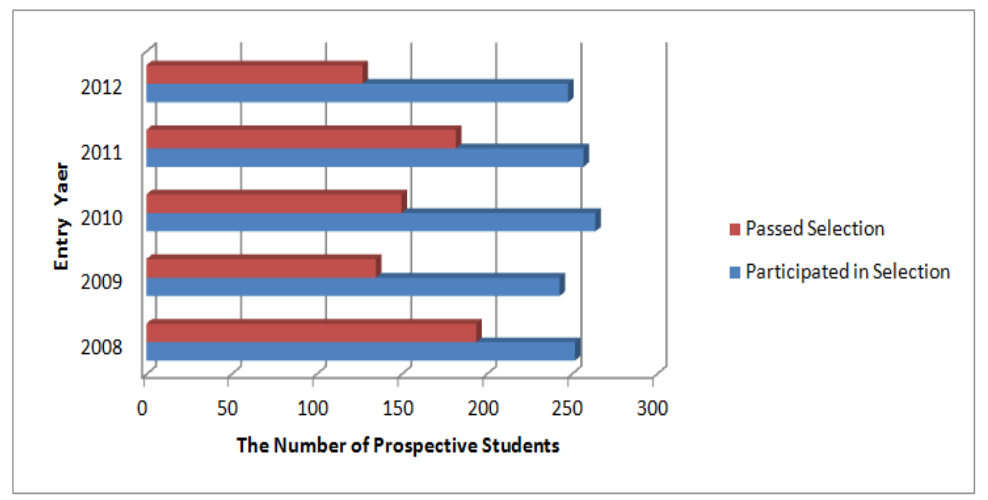

Source: Accreditation Documents of Master of Management Program FEB Unib 2012.

Figure 4 displays the declining trend relating to the number of students accepted from 2008 to 2012 . Meanwhile, the data specifically informs that the public interest to study in master of management programs tend to be stable. However, not all prospective students could pass and continue their study. Only 50-75 percent on average from the total number of students who participate in the selection process is accepted. This indicates that quality control is necessarily important.

In accordance to the in-depth interviews with 10 students who enroll in master of management, and 10 doctoral students in management program, the respondents believe that instead of different educational background, they clearly reveal the decision to continue graduate study in management science is a right decision. Furthermore, Kass \& Grandzol (2012) state that students with non-management background want to have value added which is different from the competencies acquired during their education in undergraduate program. For instance, a master degree student who has profession as a doctor decides to study in marketing management. In this context, the student wants to develop his core competence as a doctor and combining it with managerial skill, so that the profession as a doctor and his efforts can be well operationalized. By having the combination between medical insight and managerial skill, the doctor can gain more customers and build a long term relationship with the customers. Managerial skill was certainly not provided when he took medical courses, but it can be learn when he continues his study in marketing management studies.

The interviews with respondents also concentrate on extracting information relating to the focus on quality. Respondents mention that the current condition of good management courses at undergraduate level, master, and doctoral degree became a consideration when deciding to continue their studies in the field of management. In general, respondents satisfy with the mean score of reputation as 4.33 . It is identified by the quality of services that meet the expectations of users. Moreover, in line with the findings of Lee et al., (2009) learning process also helps students to understand more about the content of subjects. This implies that satisfaction has shown strong correlation between perceptions and expectations. Therefore, competence which is offered through the curriculum can be delivered properly. These all considerations are conjectured to trigger the students to choose management program.

If we trace back, management science has been dynamically and quickly developed. This advanced development brings changes and significant differences time by time. At first, the concept and managerial ability only focus on how to achieve the determined target, maximizing value, and increasing profit (Hall, 2007). In the past, Homburg \& Furst, (2005) display that targets and objectives can only be obtained by implementing the concept of mechanistic management. Consequently, the targeted plans cannot be achieved optimally. However, this phenomenon is no longer exists, this is relevant to the findings of research conducted by Neumann (2005). He shows that for the nearly decade, doctoral profession or individual who has a PhD in 
social sciences such as law, art, education, and management contribute greatly to the development of science and the broadening practical insights in Australia.

During its development, management concept has been changed from mechanistic (based on establishing guidelines) to organic (based on creating favorable internal environment) concept (Homburg \& Furst, 2005). Spencer, 1994 documents that mechanization sometimes is very bureaucratic that makes organization became less responsive to the spontaneous and flexible environment. However, the development of the concept of management has become more organic by adopting the theme of Total Quality Management (Lawrence \& McCollough, 2001). Total Quality Management (TQM) is primarily known as a strategic planning which is flexible to the adjustment of internal and external environment (Aponte, 2011). With this concept, decisionmaking process is no longer done with the concept of bureaucratic authoritarianism, but it is made democratically in order to obtain a lot of input in speeding up the process of learning organization. Thus, the dynamics relating to the process of management science is attracting a lot of businesses with mean score as 4.39 The desired competencies from graduate students are not only in terms of conceptual improvements, but also relating to the hard skills and soft skills as required by the market.

Significant development of service sector in the field of educational activities, especially management program is also conjectured as one of triggering factors of the rapid progress in economy growth. When it is viewed from the perspective of globalization and the growth of service sector such as universities, the interdisciplinary education has become a common thing. This development will eventually able to provide pressure on the competition in the market services (Yeo, 2008; Sharabi, 2013).

Globalization also contributes to the rapid development of science. This trend can be observed from the alteration of wide variety of industries, such as banking, insurance, aviation, telecommunications, retail, consultants, and others. Also, alteration is happening on the non-profit organizations such as Non Government Organizations (NGOs) that needs to be managed with the effective implementation of managerial concepts. As revealed by Maddzar \& Ciron, (2008) government institutions such as hospital and non-profit organizations can be managed effectively and efficiently when it is handled by individual who has integrity and qualified ability. The implication of this phenomenon intensively leads to the need of more competent human resources. Therefore, this factor obviously causes the managerial science become more developed and has experienced faster adjustments compared to the other disciplines.

Moreover, the invasive growing of management program and the increasing interest of prospective students provide sufficient supply of competence human resources to labor market. Brand image and brand awareness with respect to university became a major factor when students deciding to continue their studies. Also, the result of interviews with respondents reveals that in the industrial and informational era, brand is supposed to be intangible assets for consumers (Thurau et al., 2001). Brand is an entity that is very crucial as a power in the arena of market competition. The obtained results from several students in master of management program reveal that master of management program has shown good brand for its users and consumers. This is proven by the high rate of absorption of graduates from master of management program in the labor market

Study program of management is considered to accommodate the complexity and the dynamic changes in socio-economic conditions, political, and cultural with mean score as 3.75. Most of students believe that by conducting further study in the field of management studies, their analytical skills, decision-making skills, and the ability to evaluate the implementation of certain policies are getting better. This is supported by the results of in-depth interviews conducted on bureaucrat in Central Bengkulu district. Respondents said that the study undertaken by the students during their doctoral degree trains them in terms of analyzing, and implementing public policy. They realize that such policies should be certainty measured, so it can be useful as basis for refinement in other strategic policies.

\subsection{Discussion and Implication}

The theory of expectation as expressed by Robbins (2007) demonstrates that the decision to choose, and do something closely related to the motivation behind the decision. Motivation is described as a process that explains the intensity, direction, and persistence of individuals to achieve specific dreams or goals. The expectations theory itself also became one of factors that affect an individual's in making decision. The 
tendency to take a particular action is highly dependent on the strength of expectation that inclines to make the decision itself performing an action as followed by individuals. In line with the motivation expressed in this theory, maximum efforts will result in an impact and contribute to the good performance (Li \& Seale, 2007). This output will eventually be rewarded in form of rewards or recognition, in which the expectancy theory focuses on three things, such as business relationships and performance, relationship with the awarded performance, and awards relation to the objectives and personal goals.

Results of the present study show the theories of motivation, expectancy, TRA, and TPB can increase understanding with respect to the factors that affect and determine student's behavior for majoring in management studies. When all variables were examined simultaneously by employing correlation test, the output performs the existence of connection between all variables. Even though we did not examine the causality test, our results have shown that there are various considerations from the prospective students when deciding to commence their graduate or post graduate study in school of management.

As shown in the results obtained by performing quantitative and qualitative study of the 80 respondents in the graduate and post graduate students in school of management, we find that the phenomenon of continuing studies with non-management background to school of management become a new trend. This happens in particular program such as master of management, and doctorate programs in management. Virtually all of students who continue their study in these programs argue that management is a type of science which is positioned in a field of strategic management. Therefore, many people want to learn it as a provision in facing the problematic situation that is fully loaded of challenges and dilemmas either in profit or non-profit organizations.

The findings from this study also provide valuable information concerning the dynamics of management studies. According to Yeo (2008), the management of an organization without proper managerial concept will lead to the less efficient, less effective, and un-optimal implementation of corporate governance. Thus, the dynamic development of management science is attracting more prospective students with non-management background to study in graduate and postgraduate program. Their main motivation to conduct doctoral program is due to the demands of the profession that requires them to have a doctorate title. Herewith, such a title would make them able to develop in-depth capacity and capability.

These study results must be interpreted in light of the study's limitation. Although the response rate obtained from every respondent was good, given the limited number of specific respondents who take management studies even though they have no background in management, there were insufficient numbers to examine causality test among variables employed. In addition, we assumed that the individuals who completed the survey instruments were the most qualified respondents to answer the question offered.

\section{CONCLUSION}

This paper specifically presents a more thorough insight of the phenomena associated with desires, motives, and expectations behind the goals of student with non-management background to continue their study in school of management. The previous empirical research and the use of questionnaire are still implicitly based on general investigation of management sciences. Hereby, our study particularly tries to compare between management sciences and the other fields of science. The results obtained from this study also perform that decision to continue the study, quality of the delivery in educational services, motivation, and the reputation of service providers are rapidly changing the essence of knowledge management in building student capacity. We have argued that a priority consideration must be devising the high interest of the student on graduate program (Master of Management) and postgraduate program (Doctorate of Management).

In this case study, the summarized management story can be elaborated into two pertinent evidences. Firstly, we inferred that the main factor which makes the management program become more interesting and remarkably growth than the other fields of study, is relating to its ability in responding the significant changes of internal or external needs from the users. Secondly, the social science knowledge obviously performs the dynamics alteration in many kind of perspective, especially in terms of human resource management, operational and production, marketing, finance, information system, and service sector. Therefore, 
management program seems to be more interesting and shows promising progress with respect to the origin of social science.

\section{REFERENCES}

Accreditation Documents of Master of Management Program. (2012). Faculty of Economics and Business. University of Bengkulu.

Ajzen, I \& Fishbein, M. (1985). From Intention to Action: A Theory of Planned Behavior. In J. Kuhl \& J. Beckman (Eds). Action-control: from cognition to behavior (pp-11-39). Heidelberg, Germany: Springer.

Ajzen, I. (1991). The Theory of Planned Behavior. Organizational Behavior and Human Decision Process. Vol. 50,179-211.

Aponte, G, L. (2011). A Grounded Theory to Studying Strategic Planning in Higher Education: A Qualitative Research Methodology Utilizing the Literature Review and Interview. Disseration of the University of Toledo, Ohio, The United States America.

Bruce, D, G. (2010). Exploring the Value of MBA Degrees: Student's Experiences in Full Time, Part-Time, and Executive MBA Programs. Journal of Education for Business. Vol. 85 (1), 38-44.

Cooper, D. R., \& Schindler S. P. (2011). Business Research Methods, $11^{\text {th }}$ ed. New York: Mac Graw Hill/Irwin.

Cornuel, E, T, H. (2011). Business School Futures; Evaluation and Perspectives. Journal of Management Development. Vol. 30 (5), $444-450$.

Dillon, M., McCaskey, P., \& Blazer, E. (2011). MBA Interenship: More Important Than Ever. Journal of Education For Business. Vol. 86 (1), 44-49.

Dharmmesta, B S. (2002). Trying to Act: an empirical study of investigating higher education consumers. Gadjah Mada International Journal of Business. Vol. 4. (1), 45-66.

Engel, James F., Black, Roger D., Dan Miniard., Paul W. (1994). Consumer Behavior, $6^{\text {th }}$ ed. The Drydeen Press. Chicago.

Fisher, M, D., Kiang, M., \& Fisher, A, S. (2007). A Value-Added Approach to Selecting the Best Master of Business Administration Program. Journal of Education for Business. Vol. 83 (2), 72-76.

Gupta, B, P., Saunders, M, P., \& Smith, J. (2007). Traditional Master of Business Administration (MBA) Versus the MBA With Specialization: A Disconnection Between What Business Schools Offer and What Employers Seek. Journal of Education for Business. Vol. 82 (6), $307-312$.

Hall, S. (2007). Geographies of Business Education: MBA Programmes, Reflextive Business Schools and the Cultural Circuit of Capital. Transaction of the Institute of British Geogrraphers. Vol. 33 (1), 27-41.

Homburg, C., \& Furst, A. (2005). How Organizational Complaint Handling Drives Customers Loyalty: An Analysis of the Mechanistic and the Organic Approach. Journal of Marketing. Vol. 69 (3), 95-114.

Ingram, L, K., Cope, G, J., Harju, L, B., Wuensch, L, K. (2000). Applying to Graduate School: A Test of The Theory Planned Behavior. Journal of Social Behavior and Personality. Vol 15 (2), 215-225.

Kass, D., \& Grandzol, C. (2012). Evaluating the Value-Added Impact of Outdoor Management Training for Leadership Development in an MBA Program. Journal of Experiental Education. Vol 35 (3), 429-446.

Kotler, P. (2003). Marketing Management, $11^{\text {th }}$ ed. Upper Saddle River, Prentice Hall, Inc, New York.

Kreitner, R., \& Kinicki, A. (2000). Organizational Behavior, Fifth Edition, Irwin McGraw Hill.

Kuipers, L, J. (2011). PhD and EdD Degrees for Mid-Career Professionals: Fielding Graduate University. New Directions for Adult and Continuing Education. Vol. 2011 (129), 63-73.

Latham, P, G., \& Brown, C, T. (2006). The Effect of Learning vs Outcome Goals on Self Efficacy, Satisfaction and Performance in an MBA Proogram. Applied Psychology: An International Review. Vol. 55 (4), $606 \quad 623$.

Lawrence, J, J., \& McCollough, A, M. (2001). A Conceptual Framework for Guaranteeing Higher Education. Quality Assurance in Education. Vol 9 (3),139-152.

Lee, H, S., Lee, J., Liu, X., Bonk, J, C., Magjuka, J, R. (2009). A Review of Case-Based Learning Practices in An Online MBA Program: A Program-Level Case Study. Educational Technology \& Society. Vol. 12 (3), 178-190.

Li, S., \& Seale, C. (2007). Managing Critism in Ph.D. Supervision: A Qualitative Case Study. Study in Higher Education. Vol. 32 (4), $511-526$

Linden, J., Ohlin, M., \& Brodin, M, E. (2013). Mentorships, Supervisio, and Learning Experience in PhD Education. Studies in Higher Education. Vol 38 (5), 639-662.

Lussier, R.N. (1997). Management: Concepts, Application and Skills Development. USA: International Thomson Publishing. 
Madzar, S., \& Citron, P. Differences in the Roles of Core Academic and Executive Faculty in MBA Programs: Time to Explore Assumptions. Journal of Education for Business. Vol. 84 (3), 183-188.

Maslow, A, H. (1943). A Theory of Human Motivation. Phychological Review. Vol 50 (4), 370-396.

Neuman, R. (2005). Doctoral Differences: Professional Doctorate and PhDs Compared. Journal of Higher Education Policy and Management. Vol. 27 (2),173-188.

Ritz , J., \& Martin, G. (2013). Perception of New Doctoral Graduates on the Future of the Profession. Journal of Technology Studies. Vol 39 $(2), 65-78$.

Robbins, Stephen P, \& Judge, Timothy A. (2007). Organizational Behavior. Pearson/Prentice Hall.

Sharabi, M. (2013). Managing and Improving Service Quality in Higher Education. International Journal of Quality and Service Sciences. Vol. 5 (3), 309-320.

Sihombing, S, O.(2003). Perluasan Theory of Planned Behavior: Aplikasi Pada Niat dan Perilaku memilih satu merek. Empirika, Balai Penelitian dan Pengembangan Ekonomi Fakultas Ekonomi UMS, Surakarta.

Spencer, B, A. (1994). Models of Organization and Total Quality Management: A Comparison and Critical Evaluation. Academy of Management Review. Vol. 19. (3), 446-471.

Stahl, M, J., \& Herrell, A, M. (1981). Modelling Effort Decision With Behavioral Decision Theory: Toward an Individual Differences Model of Expectancy Theory. Organizational Behavior and Human Perfirmance. Vol. 27 (3), 303-325.

Thurau, H, T., Langer, M., \& Hansen, U. (2001). Modeling and Managing Student Loyalty. Journal of Service Research. Vol. 3 (4), $331-344$.

Urchick, A, S. (2004). Perceived Service Satisfaction and Its Impact on Adults' Persistence in Higher Education: A Qualitative Study of Female Adults Students From A Small Public niversity. Doctoral Dissertation, Indiana University of Pensylvania, 1-223.

Wood, B., \& Gordon, S. (2009). Linking MBA Learning and Leadership Coaching. International Coaching Psychological Society. Vol 4. (1), 87104.

Yeaple, N. R. (2010). Measuring the Economic Value of Pre-MBA Work Experience. Journal of Education for Business. Vol. 85 (1), 13-20.

Yeo, K, R. (2008). Servicing Service Quality in Higher Education: Quest for Excellence. On the Horizon. Vol 16 (3), $152-161$. 